\title{
Individual Psychology Counseling Approach to Increase Student Self-Acceptance
}

\author{
Farhan Farhan \\ Universitas Negeri Padang
}

\begin{tabular}{l}
\hline Article Info \\
\hline Article history: \\
Received Dec $8^{\text {th }}, 2019$ \\
Revised Jan $12^{\text {th }}, 2020$ \\
Accepted Feb $12^{\text {th }}, 2020$ \\
\hline
\end{tabular}

\section{Keyword:}

Konseling Psikologi Individual Self-acceptance

Peserta Didik

\begin{abstract}
The research is motivated by the author's desire to know how the students' selfacceptance / acceptance of a problem they are facing. The author uses an individualized psychological counseling approach, which feels suitable to the characteristics of the respondent in order to see his self-acceptance, which is needed in life. This research is a qualitative research with a case study approach. The study was conducted at one of the High Schools in the City of Padang. The subjects in this study were one student. Taking the subject of this study using purposive sampling method. This study uses data collection techniques with interviews and observations. The technique guarantees the validity of the data carried out by building close relationships with subjects and informants naturally and continually making observations. Data analysis technique is done by data reduction, data display and conclusion drawing and verification. The results of the study revealed that the conditions of selfacceptance of students in the case are as follows: (1) Students have good confidence in their capacity to cope with the environment, and the environment is good (2) Students consider themselves to be different from others, (3) Students consider themselves reasonable and have expectations that others will accept it, (4) Students can be said to be confident, not ashamed or self-aware, as evidenced by the achievements achieved (5) Students can be responsible for each behavior, but also doubt for the future (6) stand alone, this problem lacked opinion students proved that sometimes affected by social pressures from the community / school environment (7) students can receive objective criticism and praise, (8) students are able to accept strengths and weaknesses possessed, (9) Students do not deny all the feelings that arise. But sometimes it can change the mood to negative. So, it can be concluded that students have good self-acceptance.
\end{abstract}

(C) 2020 The Authors. Published by IICET.

This is an open access article under the CC BY-NC-SA license

(https://creativecommons.org/licenses/by-nc-sa/4.0

\section{Corresponding Author:}

Farhan Muhammad, Universitas Negeri Padang Email: farhan80farhan@gmail.com

\section{Pendahuluan}

Peserta didik rentan dalam menerima masalah yang datang dalam hidupnya. Mereka cenderung tidak bisa berpikir sehat terhadap masalah yang datang, begitupun dengan penerimaan diri mereka setelah nya. Oleh kerena itu peserta didik diharapkan memiliki self-acceptance yang baik, sehingga tidak mengganggu kehidupan efektif sehari-harinya. Salah satu cara untuk mempertahankan itu dengan pendekatan konseling psikologi individual. Secara umum konseling psikologi individual berpandangan bahwa manusia sejatinya memiliki kemampuan untuk menyelesaikan masalahnya sendiri. Manusia tidak ditentukan oleh hal-hal yang terjadi di masa lalu. Adapun tujuan konseling yang dikemukakan oleh Adler ini secara umum sangat sederhana, yaitu membantu individu dalam mengubah konsep dirinya sendiri. Kita tidak berusaha secara khusus untuk 
merobah pola tingkah laku atas gejala-gejalanya, melainkan sangat dipengaruhi diri individu sendiri. Melihat dari gejala-gejala yang diperlihatkan responden, maka peneliti meyakini dengan pendekatan ini akan bisa meningkatkan self-acceptance nya.

Self-acceptance/ penerimaan diri merupakan salah satu aspek kepribadian yang sangat penting dalam kehidupan. Setiap individu diharapkan memiliki penerimaan diri, karena dengan memiliki penerimaan diri seseorang bisa lebih mengenal dirinya sendiri. Mulai dari kelebihan sampai kekurangan diri, setelah mengetahuinya seseorang diharapkan dapat menerima kelebihan dan kekurangan yang dimiliki, serta menyiasati kekurangan dengan kelebihan. Apabila seseorang telah memiliki penerimaan diri maka ia dapat menerima dirinya dengan optimal (Lany, dkk. 2015, hlm. 160). Self-acceptance sangat dibutuhkan bagi setiap orang khususnya kaum remaja yang sedang mematangkan identitas dirinya. Remaja yang menerima diri akan memiliki evaluasi positif, merasa puas terhadap diri, dan dapat menghargai kemampuan yang dimiliki. Individu yang menerima diri adalah individu yang secara keseluruhan menerima diri sendiri, baik dalam kondisi apapun serta melengkapi kekurangan dengan kelebihan yang dimiliki (Chaplin, 2001, hlm. 178). Selfacceptance juga merupakan salah satu kompetensi kemandirian peserta didik yang harus dikuasai menurut ABKIN (2008, hlm. 253). Dimulai dengan tahap pengenalan yaitu mengenal kemampuan dan keinginan diri. Tahap akomodasi yaitu menerima keadaan diri secara positif dan tahap tindakan dengan menampilkan perilaku yang merefleksikan keragaman diri dalam lingkungannya. Selain itu, penerimaan diri juga termasuk dalam sebelas tugas perkembangan remaja yaitu menerima keadaan dirinya. Penerimaan diri setiap remaja berbeda, berdasarkan data yang peneliti dapat, peserta didik mempunyai permasalahan yaitu merasa hidupnya menyedihkan. Mengapa ia tidak bisa hidup pada keluarga yang lengkap seperti teman-temannya yang lain. Sedih dengan keadaanya karena tidak sesuai dengan orang lain, seperti sulit menerima dirinya.

Jadi penulis menilai penelitian ini cukup penting. Karena self-acceptance akan mempengaruhi kondisi psikologis peserta didik, terutama bagaimana mereka merasa senang terhadap diri sendiri, merasa lebih sehat, lebih semangat. Dengan adanya self-acceptance, peserta didik merasa diri mereka berharga, sekurang-kurangnya sama dan sejajar dengan orang lain. Karena menyadari disamping kekurangan-kekurangannya juga memiliki kelebihan-kelebihan. Pada akhirnya disadari bahwa hal tersebut akan mempengaruhi kehidupan mereka baik di sekolah, keluarga maupun masyarakat

Adapun penelitian terdahulu yaitu penelitan Resya Noor Diani (2014) dengan judul "Efektifitas Teknik Psikodrama untuk Meningkatkan Penerimaan Diri Peserta Didik". Hasilnya adalah penggunan teknik Psikodrama ini efektif untuk meningkatkan penerimaan diri peserta didik. Hal ini ditandai oleh peningkatan skor penerimaan diri pada konseli yang mengikuti intervensi konseling kelompok dengan teknik psikodrama. Menarik jika penulis meninjau penelitian Resya Noor Diani ini. Ternyata sudah ada teknik yang efektif untuk meningkatkan penerimaan diri peserta didik, namun jika dicermati lagi, teknik ini digunakan melalui konseling kelompok. Sedangkan yang peneulis lakukan menggunakan teknik Konseling Psikologi Individual yang dikembangkan Adler. Tentu terdapat perbedaan keunikan dari konseling kelompok dengan konseling individual. Contohnya pelaksanaan konseling kelompok membutuhkan beberapa orang peserta, dan juga membutuhkan tempat yang representatif. Pada kondisi dan situasi tertentu hal ini bisa aja menjadi kendala. Maka baik rasanya penulis memunculkan alternatif lain untuk meningkatkan penerimaan diri peserta didik ini melalui pendekatan konseling psikologi individual.

\section{Metode}

Penelitian ini termasuk pendekatan kualitatif dengan jenis studi kasus. Penelitian studi kasus adalah penelitian yang bertujuan mengembangkan analisis secara mendalam dari sebuah kasus tunggal atau kasus jamak (Creswell, 2007). Studi kasus mengutamakan eksplorasi dari suatu sistem yang saling terkait satu sama lain dalam beberapa hal satu kasus secara mendetail, disertai dengan penggalian data secara mendalam yang melibatkan dari beberbagai lini yang kaya akan konteks (Herdiansyah, 2015). Penulis dalam kualitatif bertindak sebagai instrumen penelitian yang memberikan gambaran tentang kondisi secra faktual dan sistematis fenomena yang dimiliki (Moleong, 2007).

Teknik pengambilan data melalui wawancara dan observasi. Responden dalam penelitian merupakan seorang peserta didik yang sedang bersekolah di SMA di Kota Padang. Sedangkan informan tambahan dengan teknik snowball, dengan maksud mendapatkan data yang pada mulanya sedikit menjadi semakin lama semakin besar dari keterangan informan tambahan (Miles \& Huberman, 1992). Informan tambahan berasal dari teman-teman responden. Adapun analisis data dengan mengikuti reduksi data, penyajian data dan kesimpulan. 


\section{Hasil dan Pembahasan}

Temuan penelitiannya, seorang siswi, sebut saja PS yang bersekolah di salah satu Sekolah Menengah Atas di Kota Padang. PS merasakan beban di hatinya karena suatu kejadian. Tepatnya pada saat kelas VIII SMP. Waktu itu PS pulang sekolah, dalam keadaan yang capek, PS langsung beristirahat ke kamarnya. Waktu istirahat PS mendengar papa dan mamanya bertengkar menggunakan bahasa Mentawai. Pada pertengkaran itu terdengarlah kata-kata yang jika diartikan ke bahasa Indonesia "katakan saja sekarang bahwa PS itu bukan anak kandung kita, sudah habis uang membiayai dia". PS mengatakan selama ini orang tuanya menganggap PS tidak paham dengan bahasa Mentawai, karena dari kecil memang diajarkan bahasa Minang. Kejadian itu membuat PS terguncang perasaannya, lalu merasa down. Namun yang menarik adalah PS datang secara suka rela untuk konseling, dengan pembawaan yang ceria, namun setelah penulis mulai mendalami konselingnya barulah PS bercucuran air mata. Pada pertemuan di kelas besarpun sepengamatan penulis PS siswa yang aktif dan cerdas.

Pada kasus ini penulis menggunakan pendekatan konseling psikologi individual. Pendekatan ini dikembangkan oleh Alfred Adler, yang berpandangan bahwa manusia bukan sebagai korban dari insting dan konflik yang dikontrol oleh sifat-sifat biologis dan pengalaman masa kecil. Teori ini Ia sebut sebagai psikologi individual (Individual Psychology) karena ia memfokuskan pada keunikan dari setiap orang dan menyangkal motif-motif biologis. Bagi Adler, yang menjadi inti dari kepribadian adalah alam sadar kita dan manusia memiliki kebebasan untuk mengatur diri dan mengarahkan diri pada tujuan kita,bukan diatur oleh faktorfaktor dari luar yang tidak dapat kita kontrol.

Selanjutnya penulis mencoba mengungkap self-acceptance PS. Self-acceptance adalah suatu tingkat kemampuan dan keinginan individu untuk hidup dengan segala karakteristik dirinya. Individu dapat menerima dirinya diartikan sebagai individu yang tidak mempunyai masalah dengan diri sendiri, yang tidak memiliki beban perasaan terhadap diri sendiri sehingga individu lebih banyak memiliki kesempatan untuk beradptasi dengan lingkungan (Hurlock, 1996). Arti lainnya adalah sikap yang pada dasarnya merasa puas dengan diri sendiri, kualitas-kualitas dan bakat-bakat sendiri, serta pengetahuan-pengetahuan akan keterbatasan-keterbatasan sendiri (Chaplin, 2005).

Selanjutnya berdasarkan data-data yang penulis dapat dari PS, penulis mencoba mengaitkannya dengan pendapat yang diungkapkan Sheerer (Cronbach, 1963, hlm. 562) menyampaikan bahwa karakteristik individu yang dapat menerima diri adalah (1) Memiliki keyakinan terhadap kapasitas diri untuk mengatasi lingkungan, (2) Menganggap dirinya sejajar dengan orang lain, (3) Menganggap diri sendiri wajar serta memiliki ekspektasi bahwa orang lain akan menerimanya, (4) Tidak malu atau sadar diri, (5) Bertanggung jawab atas setiap perilakunya, (6) Berpendirian, (7) Menerima kritik dan pujian objektif , (8) Menerima kelebihan dan kekurangan yang dimiliki, (9) Tidak menyalahkan diri sendiri atau mengingkari perasaan-perasaan yang muncul. Penelitian dilakukan kepada seorang responden yaitu PS.

\section{Memiliki keyakinan terhadap kapasitas diri untuk mengatasi lingkungan}

PS menceritakan "Dari ketek PS lai mandapekkan kasih sayang apa jo ama pak. Kebutuhan A sampai Z PS lai ndak ado yang bakurang do pak. Ditambah lo PS diikuikkan latihan silek, kebetulan apa PS tu pelatih silek pak. Jadi kalau lingkungan insya allah PS bisa manyamanannyo pak" (19082019). Jika kita terjemahkan ke bahasa Indonesia "Dari kecil PS mendapatkan kasih sayang papa dan mama pak. Semua kebutuhan PS juga tidak kurang satu apapun pak. Ditambah PS juga diikutkan latihat silat, kebetulan papa PS pelatihnya pak. Jadi kalau lingkungan insya allah PS bisa menyamankan diri pak".

Berdasarkan pernyataan di atas, PS memiliki keyakinan akan kemampuan diri dalam menyelesaikan tantangan kehidupan dan menunjukkan perilaku yang bersahabat dalam lingkungan. PS merasa lingkungan bersikap baik kepadanya, terkhusus lingkungan keluarga. Karena dari awal keluarga PS memang memperlihatkan kasih sayang yang tulus. Melengkapi segala kebutuhan PS tanpa kurang satu apapun.

2. Menganggap dirinya sejajar dengan orang lain

Berdasarkan penelusuran penulis didapatlah ungkapan dari PS "PS maraso ibo se hati pak. Yo baa dek PS ndak kayak kawan-kawan lengkap samo keluarganyo." (19082019). Jika diterjemahkan ke bahasa Indonesia "PS merasa sedih hati ini pak, kenapa PS tidak seperti teman-teman lain yang hidup dengan keluarga lengkap".

PS menganggap dirinya berada pada keadaan yang menyedihkan. Hidup tidak dengan orang tua sendiri. Sering juga membeda-bedakan dengan orang lain. Kenapa orang lain bisa hidup bersama dengan keluarga yang utuh

3. Menganggap diri sendiri wajar serta memiliki ekspektasi bahwa orang lain akan menerimanya

Temuan penelitian terhadap PS terungkap pernyataan "Setelah kejadian tu wak yo agak taguncang mah pak, tapi siap tu wak mode biaso-biaso se lai nyo pak. Wak raso sado keluargapun lah tau pak" 
(19082019). Jika kita terjemahkan ke bahasa Indonesia "Setelah kejadian itu saya merasa terguncang (hati) saya pak, tetapi setelah itu saya merasa biasa-biasa saja pak. Saya rasa semua anggota keluarga sudah tau juga pak".

Berdasarkan temuan ini dapat dinilai bahwa PS menganggap dirinya, penampilan diri secara wajar, sehingga orang lain dapat menerimanya. Setelah kejadian itu, PS bersikap seperti biasanya, seolah-olah tidak terjadi apa-apa.

\section{Tidak malu atau sadar diri}

PS menceritakan "ndak lo malu atau baa do pak. Lagian yang tau tu cuman keluarga rasonyo pak. Nan awak tetap jo jalan terusnyo pak, kok di sekolah atau di silek wak pak " (12112019). Jika kita terjemahkan ke bahasa Indonesia "Tidak malu atau bagaimana juga pak. Karena yang tau hanya keluarga saja pak. Kalau saya tetap jalan terus pak, baik itu di sekolah maupun silat saya pak".

PS memiliki kepercayaan diri dalam setiap tindakan yang diambil. Malah dapat dikatakan anak yang beprestasi. Terkhusus di bidang bela diri, PS sering mendapatkan penghargaan. Ini membuktikan PS bersikap percaya diri dan tidak malu dengan keadaannya

5. Bertanggung jawab atas setiap perilakunya

Temuan penelitian terhadap PS terungkap pernyataan berupa"yo kini dalam keadaan mode ko kan awak lah tau keadaannyo ko pak. Awak lai bisa aman-aman senyo pak, cuman diujuang ko ntah baa ko pak" (12112019). Jika kita terjemahkan ke bahasa Indonesia "Dengan keadaan yang sekarang, saya menjadi tau pak. Saya bisa untuk merasa aman-aman saja pak, hanya diujungnya nanti akan bagaimana pak".

Berdasarkan temuan di atas dapat dikatakan PS bisa bertanggung jawab namun tidak tau dimana ujungnya dan PS berani memikul tanggung jawab atas segala sikap dan perilaku yang telah diperbuat. Karena PS memilih untuk seolah-olah tidak terjadi apa-apa

\section{Berpendirian}

Berdasarkan penelusuran penulis didapatlah ungkapan "sakuat-kuatnyo wak pak, tetap jo ado keadaan yang mambuek wak lamah pak. Contoh kalau ado maisi data-data yang ado urang tuonyo pak, awak kadang acok tapikia, walaupun akta jo KK wak sasuai dan status anak kanduang pak" (12112019). Jika kita terjemahkan ke bahasa Indonesia "Sekuat-kuatnya saya pak, tetap saja ada keadaan yang membuat saya lemah pak. Contoh kalau ada mengisi data-data tentang orang tua pak, saya terkadang teringat kembali, walaupun akta dan KK saya sesuai dan status anak kandung pak".

Bisa dikatakan PS terkadang terpengaruh terhadap tekananan-tekanan sosial dari masyarakat/ lingkungan sekolah. Contohnya ketika pengisian angket yang mencantumkan mengenai orang tua.

\section{Menerima kritik dan pujian objektif}

Untuk poin ini hal yang di ungkapkan PS yaitu "kalau soal kritik dan pujian wak biaso-biasonyo pak, ndak ado baper-baper tu do pak. Asal elok-elok sopan jo mangecekkan nyo" (12112019). Jika kita terjemahkan ke bahasa Indonesia "Kalau soal kritik dan pujian saya biasa-biasa saja pak, tidak ada bawa perasaan pak. Asalkan bicaranya baik-baik dan sopan".

Bisa dikatakan bahwa PS mampu menerima pujian secara objektif sehingga tidak bersikap berlebihan dan dalam menerima kritik tidak mudah tersinggung sehingga dapat menerima kritik sebagai masukan agar lebih baik.

\section{Menerima kelebihan dan kekurangan yang dimiliki}

PS mengatakan "kalau kelebihan wak raso yo di bidang silek tu nyo pak. Dek lah barakali lo wak juara lomba tu pak. Tapi yo kekurangan nan nampak bana di keluarga tadi pak, walaupun ama apa jo ama wak kini elok, tapi tetap jo wak maraso baa gitu pak" (19082019). Jika kita terjemahkan ke bahasa Indonesia "Kalau kelebihan saya rasa di bidang silat itu pak. Karena sudah beberapa kali juara lomba pak. Tapi kalau kekurangan yang terlihat sekali, di keluarga tadi pak, walaupun papa dan mama saya baik pak, tapi tetap saja saya merasa bimbang pak".

Jadi dalam menerima kelebihan dan kekurangan PS cenderung memiliki penilaian yang realistik akan kelemahan dan kelebihan diri, serta mampu mengembangkan diri.

9. Tidak menyalahkan diri sendiri atau mengingkari perasaan-perasaan yang muncul

Berdasarkan penelusuran penulis didapatlah ungkapan "kalau manyalahan diri ndak lo do pak, cuman baa dek harus ka wak masalah mode ko tibo nyo. Jadi adolo kadang-kadang tibo pangana kayak gitu pak" (12112019). Jika kita terjemahkan ke bahasa Indonesia "Kalau menyalahkan diri sendiri, tidak juga pak. Hanya kenapa harus saya yang mendapatkan masalah seperti ini. Jadi kadangkadang muncul pikiran seperti itu pak".

Bisa dikatakan PS tidak mengingkari berbagai perasaan yang dirasakan, dia lebih kepada bingung dan kecewa kenapa hal seperti ini terjadi kepadanya. PS merasakan perasaan negatif disuatu kondisi tertentu, yang membuat mood nya rusak dan tidak ingin melakukan apa-apa 


\section{Kesimpulan}

Hasil penelitian terungkap bahwa kondisi penerimaan diri PS adalah sebagai berikut: (1) PS memiliki keyakinan yang baik terhadap kapasitas diri untuk mengatasi lingkungan, dan lingkungannyapun baik (2) PS menganggap dirinya berbeda dengan orang lain, dengan kata lain penerimaan dirinya kurang (3) PS menganggap diri sendiri wajar serta memiliki ekspektasi bahwa orang lain akan menerimanya, (4) PS bisa dikatakan percaya diri, tidak malu atau sadar diri, dibuktikan dengan prestasi yang diraih (5) PS bisa bertanggung jawab atas setiap perilakunya, namun ada keraguan juga. Jadi penerimaan dirinya kurang (6) Berpendirian, soal ini PS kurang berpendirian terbukti PS terkadang terpengaruh terhadap tekananan-tekanan sosial dari masyarakat/ lingkungan sekolah (7) PS bisa menerima kritik dan pujian objektif , (8) PS mampu menerima kelebihan dan kekurangan yang dimiliki, (9) PS tidak menyalahkan diri sendiri atau mengingkari perasaan-perasaan yang muncul. Jadi, dapat disimpulkan bahwa PS memiliki self-acceptance yang cukup baik.

\section{Ungkapan Terima Kasih}

Penulis mengucapkan terima kasih kepada Bapak Amriman M, S.Pd., M.M selaku kepala sekolah yang memberikan kesempatan untuk meneliti di tempat beliau. Terima kasih juga penulis ucapkan kepada Ibu Narmiati S.Pd., Kons selaku guru BK di sekolah tersebut. Terima kasih juga penulis ucapkan kepada keluarga yang selalu medukung dan mendoakan. Selanjutnya teman-teman sejawat yang senantiasa memberikan kritik dan sarannya dalam proses penelitian ini. Semoga penelitian ini bisa memberi manfaat bagi banyak orang terkhusus di lingkup BK.

\section{Referensi}

ABKIN. (2008). Penataan Pendidikan Profesional Konselor dan Layanan Bimbingan dan Konseling dalam Jalur Pendidikan Formal. Bandung : Departemen Pendidikan Nasional.

Chaplin, J.P. (2004). Kamus lengkap psikologi (diterjemahkan oleh Kartini Kartono). Jakarta: PT. Rajagrafindopersada.

Creswell, J. W. (2007). Research Design. (Diana E. Axelsen, Ed.) (Second Edi). London and New delhi: Sage Publication

Cronbach, L.E. (1963). Educational psychology. New York: Harcourt Brace and Co.

Herdiansyah, H. (2015). Metodologi Penelitian Kualitatif untuk Ilmu Psikologi. (Rosidah, Ed.) (1st ed.). Jakarta: Salemba Humanika. Retrieved from http://www.penerbitsalemba.com

Hurlock, E. B. (1996). Psikologis Perkembangan: suatu pendekatan sepanjang rentang kehidupan. Jakarta: Erlangga

Ifdil, \& Taufik. (2012). Urgensi peningkatan dan pengembangan resiliensi siswa di Sumatera Barat. Pedagogi, $X I I(2), 115-121$.

Lany F., dkk. (2015).Efektivitas teknik permainan untuk meningkatkan penerimaan diri siswa. Jurnal Ilmu Pendidikan dan Pengajaran 2 (2), hlm.156-165.

Miles, M. ., \& Huberman, A. . (1992). Analisis Data Kualitatif Buku Sumber Tentang Metode-Metode Baru. Jakarta: UI Press.

Moleong, L. . (2007). Metodologi Penelitian Kualitatif (23rd ed.). Bandung: PT. Remaja Rosdakarya.

Resya Noor Diani. (2014). Efektivitas Teknik Psikodrama untuk Meningkatkan Penerimaan Diri Peserta Didik. Universitas Pendidikan Indonesia. repository.upi.edu 